\title{
Climate change as a possible driver of invasion and differential in HSP70 expression in two genetically distinct populations of the invasive killer shrimp, Dikerogammarus villosus
}

\author{
Kamil Hupało $₫$ H. Wolfgang Riss $\cdot$ Michał Grabowski $\cdot$ Jacqueline Thiel • \\ Karolina Bạcela-Spychalska • Elizabeth I. Meyer
}

Received: 30 May 2017 / Accepted: 24 January 2018/Published online: 2 February 2018

(C) The Author(s) 2018. This article is an open access publication

\begin{abstract}
Global climate change is known to affect physiological processes in charge of cellular stress response. That often results in forcing many organisms to shift their biogeographic distribution ranges. It also holds true for euryoecious and highly invasive species like the killer shrimp, Dikerogammarus villosus. In this study we compare the level of response to thermal stress in two genetically diversified populations of the amphipod D. villosus on the cellular level, namely HSP70 expression. The results show clear difference in HSP70 expression, that can be a direct consequence of the different climatic conditions both populations faced along their invasion routes. We conclude that the eastern population of $D$. villosus is more sensitive to thermal stress than the western population, hence its
\end{abstract}

Electronic supplementary material The online version of this article (https://doi.org/10.1007/s10530-018-1679-2) contains supplementary material, which is available to authorized users.

K. Hupało $(\bowtie) \cdot$ M. Grabowski · K. Bącela-Spychalska Department of Invertebrate Zoology and Hydrobiology, University of Lodz, Lodz, Poland e-mail: kamilhupalo@gmail.com

H. W. Riss · E. I. Meyer

Department of Limnology, Institute of Evolution and Biodiversity, University of Münster, 48149 Münster, Germany

J. Thiel

Institute for Zoophysiology, University of Münster, 48143 Münster, Germany invasion potential may be lower than that of the latter. Considering the thermal tolerance of both populations and global warming, we can make some predictions about further spread of $D$. villosus, including the possibility of an emergence of the super-invader that may arise after cross-breeding of both populations, imposing even larger threat to the freshwater ecosystems.

Keywords Dikerogammarus villosus · Heat shock · Biological invasion - Climate change $\cdot$ Thermal stress

\section{Introduction}

Physiological stress results in energetically costly responses on cellular level, which may diminish the ability of an individual to compete for resources or to reproduce (Sorte and Hofmann 2005; Tomanek and Zuzow 2010). Thus, from the evolutionary point of view, organisms are more successful if they cope more effectively with the physiological effects of stress and respond to it with a lower energy expense (Henkel and Hofmann 2008). The heat shock proteins (HSP) play a key role in enhancing the tolerance of organisms to unfavorable environmental conditions (Kültz 2003). They are responsible for many cellular processes, but above all, they serve as molecular chaperons which bind with denaturized proteins, refold reversibly denatured proteins, and facilitate the degradation of 
irreversibly damaged proteins (Lindquist and Craig 1988; Tomanek and Sanford 2003). Elevated temperature or salinity and presence of toxic substances cause the immediate cellular stress response (CSR). One of the main factors of CSR is the expression of heat shock proteins, a well-known cellular stress response in a majority of living organisms (Shatilina et al. 2011). One of the best known markers of physiological stress is the $70 \mathrm{kDa}$ HSP (HSP70) (Kültz 2003). Its synthesis may be activated by any stress factor, which makes HSP70 a good indicator of response to environmental changes (Lee and Vierling 2000). It was proven in numerous studies, that higher HSP70 expression indicates higher sensitivity of an organism to thermal stress (Tomanek and Somero 2000; Morris et al. 2013; Cottin et al. 2015).

Global climate change is known to be one of the main causes for which many organisms shift their biogeographic distribution ranges (i.e. Walther et al. 2002; Genner et al. 2004; Both et al. 2006; Parmesan 2006; Møller et al. 2008; le Roux and McGeoch 2008; Steltzer and Post 2009). Physiological processes that set thermal tolerance limits are thought to determine or at least contribute to some of the shifts that have been observed (Tomanek 2008; Chown et al. 2010). There are few studies directly linking the range shifts with the physiological tolerance limits (Pörtner and Knust 2007) while many more estimate the correlation between the temperature rise and adaptive variation between closely related organisms found worldwide and gene and protein expression, protein thermal stability, enzyme kinetic properties or heart rate (Hochachka and Somero 2002). The global warming most heavily affects the highly-specialised species inhabiting very particular habitats. Warm-adapted species, including tropical terrestrial endemics, intertidal invertebrates occurring high along the subtidalto-intertidal gradient, and cold-adapted stenothermal species such as ectotherms of the Southern Ocean, appear to be most vulnerable to climate change. Warming rates are generally greatest at high latitudes, so Arctic and Antarctic species that currently face temperatures close to their thermal limits might be among the first species to experience severe stress from global warming and may have the least time available to undergo adaptive evolutionary change (Somero 2010). On the other hand, there is increasing evidence that the ability of eurythermal organisms to adjust their physiology to increasing temperature is limited. The studies suggest that these organisms have maximized their biochemical safety factor, which does not allow for further adjustments to even higher temperatures (Tomanek 2010). However, it is a different story for the invasive species, which seems to thrive in the wake of the global temperature rise. Although some of them have diminished their negative impact, others are even more successful in outcompeting the native fauna with many new invades emerging due to the climate change (Hellmann et al. 2008; Rahel and Olden 2008).

Biological invasions are one of the major threats to biodiversity in terrestrial, freshwater and marine ecosystems around the world (Lövei 1997; Dextrase and Mandrak 2006; Lambertini et al. 2011; Früh et al. 2012). In fresh waters, the highest number of invasive species belongs to fish, molluscs, and crustaceans (Bij de Vaate et al. 2002; Strayer 2010; Früh et al. 2012). There are at least 54 non-indigenous species of crustaceans reported from different parts of Europe (Holdich and Poeckl 2007). The majority (approx. 20 species) belongs to the amphipods, with nine species being considered as highly invasive (Grabowski et al. 2009). The problem of mass colonisation by alien amphipods applies to most of major European rivers, such as Danube, Rhine, Rhone, Vistula, Oder, and their main tributaries as well as to major artificial waterways joining different river systems such as Mittelland Kanal in Germany (Jażdżewski and Konopacka 2000; Bij de Vaate et al. 2002; Bollache et al. 2004; Jażdżewski et al. 2005; Grabowski et al. 2007a, 2009). The newcomers not only successfully outcompete, but also eliminate the native amphipods and other macroinvertebrates (Dick and Platvoet 2000; Jażdżewski et al. 2004; Grabowski et al. 2009). If compared to native, the invasive amphipod species are characterized by several specific life history traits, such as high fecundity, early maturation, and high number of generations per year, which enable them to colonize successfully new water basins (summarized by Grabowski et al. 2007b). The invaders are also less vulnerable to habitat loss (Havel et al. 2005; Johnson et al. 2008) and to environmental stress such as high temperatures (Wijnhoven et al. 2003; Weitere et al. 2009; Sargent et al. 2011), oxygen deficiencies (MacNeil et al. 2000) or salinity fluctuations (Grabowski et al. 2009).

Our study focuses on one of the most recent, most invasive, and fastest spreading amphipod in Europe, 
i.e. Dikerogammarus villosus (Sowinsky, 1894) aka "the killer shrimp", that won the moniker due to its predatory abilities and voraciousness (summarized in Rewicz et al. 2014). Like many other invasive species occurring in Europe, the killer shrimp originated from the Ponto-Caspian region and its native range includes lower courses of large rivers belonging to basins of Black, Azov and Caspian seas (Mordukhai-Boltovskoi 1969; Rewicz et al. 2014). And as other Ponto-Caspian species, the killer shrimp has colonized Western and Central Europe through artificial canals connecting the drainage basins of the main European rivers and opening up several so-called migration corridors (Fig. 1) (Bij de Vaate et al. 2002; Panov et al. 2009).

The first invasion wave of $D$. villosus came along the so-called western route (for definition see Rewicz et al. 2015). Outside its native range, the species was reported first from the Danube in 1926 (Nesemann et al. 1995). From there it spread along the Danube and then, via artificial canals, to the Rhine system, from where it moved eastwards along the Mittelland Kanal, reaching the Oder River in 1999 (Jazdzewski et al. 2002). Almost at the same time, the killer shrimp dispersed through the eastern route. It crossed the Black Sea/Baltic Sea watershed and was found in the Bug River in 2003 (Konopacka 2004) and in the Vistula River in 2008 (Baccela et al. 2008). In result, there are two opposite invasion fronts of the killer shrimp in Central Europe, both on the territory of Poland (Grabowski et al. 2007a). At the moment, the fronts are separated by ca. $150 \mathrm{~km}$ long stretch of the Bydgoski Canal that neither of the populations has crossed yet (Rewicz et al. 2014, own unpublished data). Recent phylogeographic studies corroborated that the Oder population originated from the Danube and that it differs in genetic structure from the Vistula population that expanded from the Dnieper River (Rewicz et al. 2015). It cannot be excluded that the two populations are likely to come into contact in the near future leading to a hybridisation event.

The two invasion routes of $D$. villosus pass through regions of Europe differing in climatic conditions. The

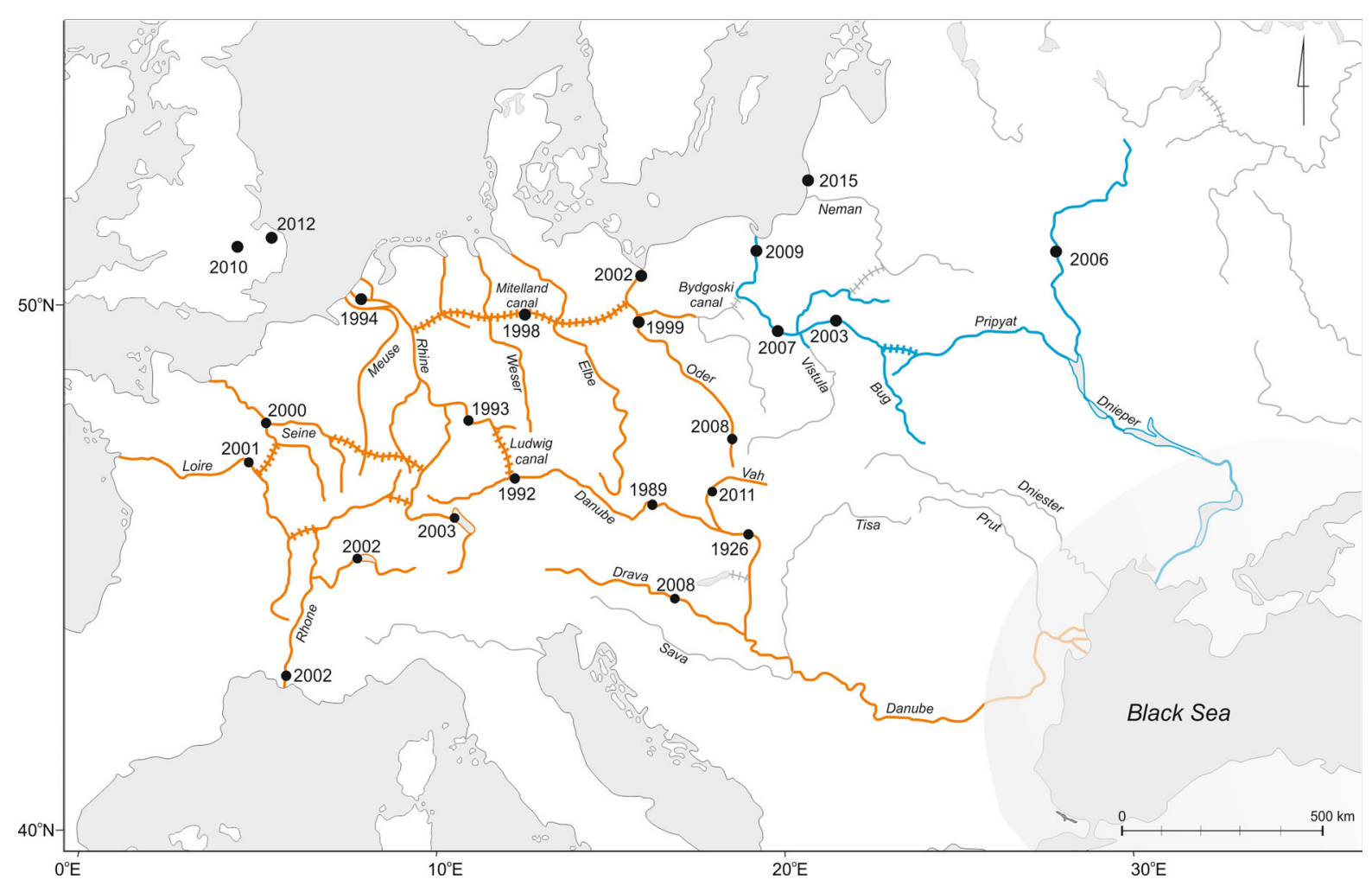

Fig. 1 Distribution of Dikerogammarus villosus in its native region around the Black Sea (shaded area) and along eastern (blue) and western (orange) invasion routes to central Europe as well as to the UK, along with dates of first reports for particular sites (modified after Rewicz et al. 2015 and Šidagytė et al. 2017). Solid lines are rivers, dashed lines mark canals 
eastern route leads via territories of predominantly harsher continental climate, characterized e.g. by lower mean year temperatures than those observed for the western route. The western route leads mainly via territories influenced by the Mediterranean and Atlantic climate, resulting in milder thermal conditions. Also in their native regions, the Dnieper and the Danube deltas, the climatic conditions vary (Tockner et al. 2009). Given the different genetic background of the two invasive populations of the killer shrimp, different invasion history and different climatic conditions in the source region and along the invasion routes, we hypothesized that they may differ in response to environmental stress posed by the local climatic, i.e. thermal, conditions in the invaded range. If true, it could provide some background information to explain the present distribution pattern of both killer shrimp populations in Europe and to assess the risk of colonizing new areas. It is a very up-to-date problem, taking into account the high invasive potential of the killer shrimp and its effective spread (i.e. Ba et al. 2010; Boets et al. 2012; Gallardo et al. 2012).

We aimed to approach the problem by (1) measuring and comparing in experimental conditions the level of response to thermal stress in both invasive populations of $D$. villosus on the cellular level, namely HSP70 expression; (2) interpreting the results in the context of climatic-geographical conditions, and (3) drawing conclusions with respect to the possible further spread of these populations in Europe.

\section{Materials and methods}

\section{Test material}

Two populations of Dikerogammarus villosus, one from the western route and one from the eastern route were used for the experiment. The western population was sampled from the Rhine River, near Götterswickerhamm, Germany $\left(51.58^{\circ} \mathrm{N}, 6.67^{\circ} \mathrm{E}\right)$, while the eastern population was sampled from the Vistula River, near Wyszogród, Poland $\left(52.39^{\circ} \mathrm{N}, 20.19^{\circ} \mathrm{E}\right)$. Samples were collected twice, in October/November 2012 and in January/February 2013. In laboratory conditions, the animals were kept in $30 \mathrm{~L}$ aquaria at $10{ }^{\circ} \mathrm{C}$, which corresponded to the seasonal temperature of the waterbodies they had been collected from. Near-natural light conditions and a light:dark cycle of
10:14 h were provided. Animals were fed ad libitum with chironomid larvae and commercial fish food (Tetra-Min, Tetra GmbH, Germany).

Experimental protocol

In the experiment, test animals were exposed to an elevated temperature of $27{ }^{\circ} \mathrm{C}$. This temperature was chosen following Mazzouzi et al. (2011), as it poses strong stress on the studied animals, yet is not lethal in short-term experiments, what had been confirmed by preliminary lethal temperature essays (data not shown). Prior to the experiment, thirty individuals of each $D$. villosus population were firstly accustomed for $1 \mathrm{~h}$ to room temperature and then kept at a temperature of $27^{\circ} \mathrm{C}$ for $12 \mathrm{~h}$ in two separate aquaria. Control animals were kept the same way but at keeping temperature of $10{ }^{\circ} \mathrm{C}$. Five randomly chosen individuals from each aquarium were collected $0.5,1$, 3, 6, and $12 \mathrm{~h}$ after onset of the $27{ }^{\circ} \mathrm{C}$. Sampled individuals were immediately shock frozen in liquid nitrogen for the subsequent procedure. Before analysis, the gut was removed from the body not to affect HSP results. Due to the fact that abundance of $D$. villosus in Rhine was relatively low if compared to Vistula, the numbers of animals used for experiment differed between populations (270 from Vistula and 120 from Rhine). Thus, nine replicates for Vistula and four replicates for Rhine population were used.

\section{HSP analysis}

Each individual was hand-homogenized in a mortar on normal ice and centrifuged at $7000 \mathrm{~g}$ for $15 \mathrm{~min}$ at 4 ${ }^{\circ} \mathrm{C}$. After centrifugation, the supernatant was dissolved in a sample buffer $(0.0625 \mathrm{~mol}$ Tris, 1 mmol EDTA, $1 \%$ SDS, $20 \%$ glycerin, $5 \%$ b-mercaptoethanol, and $0.001 \%$ bromophenol blue, $\mathrm{pH}=6.8$ ). The total protein concentration in a sample was determined following the assay proposed by Bradford (1976). The HSP content of the samples was analysed through SDS electrophoresis followed by Western blotting using anti-HSP70 primary antibodies (monoclonal anti-heat shock protein 70 antibody produced in mouse, Sigma\#H5147) and anti-Actin antibodies (Anti-Actin antibody produced in rabbit, Sigma\#A2668), as actin was used as a reference protein. SDS electrophoresis was performed in polyacrylamide gel blocks $\left(70 \times 80 \times 1 \mathrm{~mm}^{3}\right.$; Laemmli 1970) using a Mini- 
PROTEAN II electrophoretic cell apparatus (BIORAD, USA). Western blotting to the nitrocellulose membrane was done according to Towbin et al. (1979). Equal loading of protein was verified by staining the membranes with Ponceau Red. After blotting, the membranes were blocked in $2.5 \%$ non-fat dry milk solution. Staining of the membranes was done according to the previously developed protocol for amphipod species as described in Bedulina et al. (2010). For HSP70 measurement, blots were incubated in primary antibodies, for HSP70 dissolved 1:5000 and for actin dissolved 1:3000 in blocking solution for $1.5 \mathrm{~h}$. After two-fold washing, the blots were treated in secondary antibodies (Anti-Mouse IgG, Sigma A9044; Anti-Rabbit IgG, Sigma A9169) dissolved 1:10,000 (for HSP70) and 1:8000 (for actin) in blocking solution for $2 \mathrm{~h}$.

After antibody staining, membranes were analysed using a FluorChem Q device with a ChemiGlow Kit for fluorescence analysis. For further statistical analyses, the expression of HSP was measured in relation to expression of actin as the reference protein which served as a housekeeper. Measurement of expression rates was done with image analysis software on the digital fluorescence photos of the blots.

\section{Climatic data}

As an approximation of environmental conditions along the two invasion routes, we used annual means of air temperatures compiled, covering a period of 40 years, for 19 locations on the following rivers (Table 1, supplementary material): Eastern route (E) including Dnieper, Vistula, Bug and Western route (W) including Danube and Oder. Data were obtained from public online sources (http://en. tutiempo.net) and encompassed 8 sites for the eastern route and 11 sites for the western route spanning the reaches between the area of origin and two invasion routes of the killer shirmp. For analysis of spatiotemporal differences and dynamics between preinvasion period and the actually observed phase of massive invasion progress (see Rewicz et al. 2014 for the exact invasion chronology), four reference sites of similar distance to each other were chosen for the upper (E.upr: Warsaw on Vistula river, W.upr: Vienna on Danube river) and lower (E.lwr: Dniepropetrovsk on Dnieper river, W.lwr: Bucharest on Danube river) section of the invasion corridor and the corresponding temperature data were split into two consecutive vicennia (v1: 1973-1993 and v2: 1994-2014).

Statistical analyses

Expression rates were determined by integrating pixel numbers and intensity values (16 bit, $0.4 \%$ overexposure limit) of HSP and actin bands from digital fluorescence images of the membrane using ImageJ software (http://imagej.nih.gov/ij/index.html). Statistical analysis accounted for positive skew of readout data and a non-linear two-peaked response. Data were $\log (\mathrm{x}+1)$ transformed and modeled as a 4th-degree polynom using a Generalized Linear Model (GLM) with Gamma error and log-link. Sampling season was included as a co-factor of the model. Analysis of deviance (AOD, $F$-test, type II error) was done on Pearson residuals. For planned (meaningful) post-hoc comparisons, model contrast values were evaluated with a Welsh test. Combined standard errors of contrasts were approximated with Gauss' error propagation. Type-1 error inflation after multiple testing was limited following Holm (1979).

Temporal course of climatic data from the two invasion corridors over 40 years were modelled with a Generalized Additive Model (GAM), using a regression spline with fixed degrees of freedom. Unimodal probability distributions of temperatures were obtained for each year and corridor after individual exponential transformation and fitting of a Gauss function. Distinctness of temperature was assumed under combined probabilities $P<0.05$ for identical or overlapping temperatures occurring. Temperature means were given with standard deviations (SD) as measure of dispersion, slopes (changes of temperature over time) were given with standard errors (SE). Differences between temperature distributions or changes over time were determined and tested as linear relationships using a Generalized Linear Model (GLM) with Gauss-type error and identity link. For the full model, determinant variables were defined as sections nested in corridors and years nested in vicennia. Analysis of deviance (AOD, F-test, type II error) was carried out on the Pearson residuals of the model. Planned (meaningful) post-hoc comparisons of temperature data were performed with multiple Welsh tests (normality of residuals provided). As above, combined standard errors of contrasts were approximated with Gauss' error propagation. Multiple testing 
effects were controlled with Holm (1979) adjustment of significance. Statistical analyses were done with R (R Core Team 2015).

\section{Results}

\section{HSP expression}

Expression of HSP70 was analysed in a total of 390 individuals, 270 from the Vistula population (eastern route) and 120 from the Rhine population (western route). Test animals from the two populations revealed clearly different patterns of HSP70 expression over time during exposure to a temperature of $27{ }^{\circ} \mathrm{C}$. As the most distinct characteristic, the amplitude of expression was significantly higher in the eastern population (AOD, $\mathrm{F}_{1,328}=57.4, P<0.001$ ) (Fig. 2). But also the progressions of response over time differed significantly (AOD, $\left.\mathrm{F}_{4,328}=5.42, P<0.001\right)$ between the two populations.

At the start of the experiment, basic levels of HSP70 were a level not significantly different between the populations (Table 1). However, after $30 \mathrm{~min}$ of exposure animals from the eastern route exhibited an increase of relative HSP70 levels with a peak at 370\% of the basic value (Welsh test: $\mathrm{t}_{\mathrm{W}}=4.35, \mathrm{df}_{\text {eff }}=78, P<$ 0.001 ), significantly higher than the corresponding levels in individuals from the western corridor (Welsh test: $\left.\mathrm{t}_{\mathrm{W}}=4.97, \mathrm{df}_{\mathrm{eff}}=54, P<0.001\right)$. The rapid HSP70

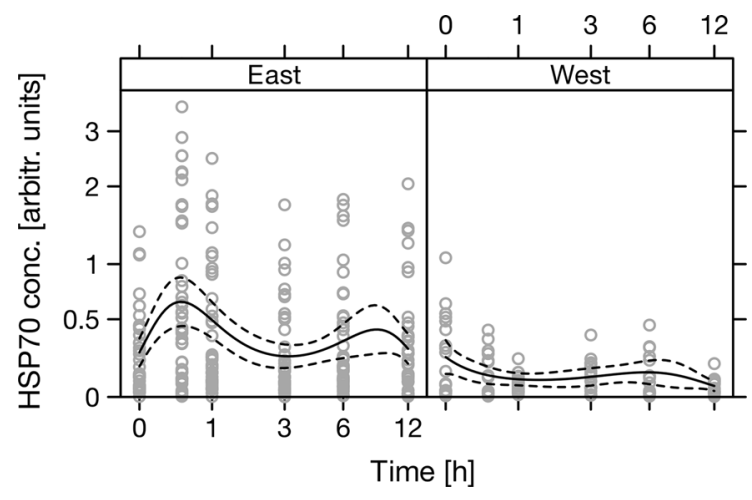

Fig. 2 HSP70 expression of D. villosus after experimental exposure to heat shock. Test individuals from populations of the eastern (East) and the western (West) invasion corridor. Based upon the models describing the temporal pattern, expression rates of the populations are significantly different in both amplitudes (AOD: $\mathrm{F}_{1,328}=57.4, P<0.001$ ) and temporal progression $\left(\mathrm{AOD}, \mathrm{F}_{4,325}=5.42, P<0.001\right)$ response in the eastern population was followed by a gradual decrease of expression rate. This pronounced amplitude was not observed in the western population where HSP70 expression remained relatively constant at low levels throughout the whole experiment. Despite the steady decrease of HSP70 expression in the eastern population, concentrations remained at a higher level compared to the western population, and significantly different even after $1,6 \mathrm{~h}$, and at the end of the experiment (after $12 \mathrm{~h}$ of heat exposure) (Welsh test: $\mathrm{t}_{\mathrm{W}}>2.93, \mathrm{df}_{\mathrm{eff}}>54, P<0.04$ ) (Table 1 ).

Impact of climatic conditions on invasion process

Temperature conditions were hypothesized as key variable explaining great part of the invasion progress in D. villosus. At first view, the temporal developing of the annual mean air temperatures in the two invasion corridors exhibited a distinct pattern during the study period of four decades (Fig. 3a). The most conspicuous feature was a significant and steady increase of temperatures in both the eastern $\left(0.039 \pm 0.004_{\mathrm{SE}}{ }^{\circ} \mathrm{C}\right.$ $\times \mathrm{a}^{-1}$, AOD: $\left.\mathrm{F}_{1,331}=82.6, P<0.001\right)$ and the western $\left(0.036 \pm 0.005_{\mathrm{SE}}{ }^{\circ} \mathrm{C} \times\right.$ year $^{-1}, \mathrm{AOD}: \mathrm{F}_{1,402}=52.1$, $P<0.001)$ corridor. This trend was not significantly different between the corridors (AOD: $\mathrm{F}_{1,733}=0.18$, $P=0.70$ ). Accounting for the simultaneous and nearly linear increase over time, the mean annual temperature in the western corridor was constantly and significantly higher by $\Delta_{\mathrm{E}-\mathrm{W}}=1.86 \pm 1.99_{\mathrm{SD}}{ }^{\circ} \mathrm{C}$ on average (AOD: $\mathrm{F}_{1,733}=514.6, P<0.001$ ). The oscillation visible in both data sets was not significantly based on one cyclic function only. Despite the high variability of temperature measurements within each corridor, the probability that mean annual temperatures of both invasion corridors occurred to be equal or even inverted (i.e. the eastern corridor being warmer than the western corridor) was lowest in 1996 (GAM: $P<$ 0.01 , Fig. $3 b$ ) and greatest, though still significantly improbable, in 2012 (GAM: $P<0.03$, Fig. 3c).

The spatial representation revealed that warming of climate led to a significant approximation of the temperatures at the more distant sites of the invasion routes to those which initially characterized the region D. villosus originated from (Fig. 4). In order to exemplify this effect of climate warming on the invasion process, temperature data were broken down to eight subsets (Fig. 5): two consecutive sections (upr and lwr) represented by sites which were temporal 
Table 1 HSP70 expression of D. villosus after experimental exposure to heat shock

\begin{tabular}{|c|c|c|c|c|c|}
\hline \multicolumn{2}{|c|}{ Contrast levels } & \multirow{2}{*}{$\begin{array}{l}\text { Difference } \\
\Delta_{\text {conc }} \pm \mathrm{SE}_{\Delta}\end{array}$} & \multicolumn{3}{|c|}{ Significance } \\
\hline Corridors & Time (h) & & $\mathrm{T}$ & $\mathrm{Df}_{\text {eff }}$ & $P_{\text {adj }}$ \\
\hline \multirow[t]{6}{*}{ East-West } & 0 & $-0.03 \pm 0.28$ & 0.41 & 57 & 1 \\
\hline & 0.5 & $-0.52 \pm 0.49$ & 4.97 & 54 & 0.001 \\
\hline & 1 & $-0.40 \pm 0.36$ & 5.51 & 56 & 0.001 \\
\hline & 3 & $-0.13 \pm 0.20$ & 2.59 & 56 & 0.09 \\
\hline & 6 & $-0.20 \pm 0.29$ & 2.93 & 54 & 0.04 \\
\hline & 12 & $-0.23 \pm 0.23$ & 5.44 & 56 & 0.001 \\
\hline \multirow[t]{5}{*}{ East } & $0-0.5$ & $0.38 \pm 0.52$ & -4.35 & 78 & 0.001 \\
\hline & $0-1$ & $0.23 \pm 0.41$ & -1.85 & 76 & 0.51 \\
\hline & $0-3$ & $-0.02 \pm 0.27$ & -0.10 & 77 & 1 \\
\hline & $0-6$ & $0.08 \pm 0.33$ & -1.02 & 77 & 1 \\
\hline & $0-12$ & $0.02 \pm 0.30$ & -0.54 & 77 & 1 \\
\hline \multirow[t]{5}{*}{ West } & $0-0.5$ & $-0.11 \pm 0.22$ & 1.28 & 33 & 1 \\
\hline & $0-1$ & $-0.13 \pm 0.21$ & 3.19 & 37 & 0.02 \\
\hline & $0-3$ & $-0.12 \pm 0.22$ & 1.86 & 36 & 0.51 \\
\hline & $0-6$ & $-0.09 \pm 0.23$ & 1.59 & 34 & 0.67 \\
\hline & $0-12$ & $-0.17 \pm 0.21$ & 4.07 & 36 & 0.001 \\
\hline
\end{tabular}

Test individuals from populations of the eastern (E) and the western (W) invasion route. Multiple comparisons of concentrations and tests between contrast levels: population (E, W) and sampling times (0 to $12 \mathrm{~h}$ ). Parameters: difference of mean concentrations $\left(\Delta_{\text {conc }}\right)$, standard error of difference $\left(\mathrm{SE}_{\Delta}\right)$. Location test: $\mathrm{t}$ statistic $(\mathrm{t})$, effective degrees of freedom $\left(\mathrm{df}_{\text {eff }}\right)$ - $\mathrm{degrees}$ of freedom of model $\mathrm{df}_{\text {mod }}=326$ for all contrast levels, adjusted $($ Holm $)$ significance level for multiple Welch tests $\left(\mathrm{P}_{\mathrm{adj}}\right)$

thresholds of the invasion and the two vicennia (v1 and v2) for each of the two invasion corridors ( $E$ and $W)$. These eight data sets were contrasted with each other and analysed as potential determinants for the spread of D. villosus into Western and Central Europe and the simultaneous development of the two stress response variants in the species (Table 2). During the first vicennium (1973-1993), i.e. before the main phase of the invasion started, mean temperatures were relatively cool at the regions of origin, the lower route sections, and did not differ significantly from the upper sections in both the eastern corridor (E.upr.v1: $8.0 \pm$ 0.9 ${ }_{\mathrm{SD}}{ }^{\circ} \mathrm{C}$, E.lwr.v1: $8.5 \pm 1.1_{\mathrm{SD}}{ }^{\circ} \mathrm{C}$, Welsh test: $\mathrm{t}_{\mathrm{W}}=$ 1.58 , df $=40, P=0.24)$ and the western corridor (W.upr.v1: $9.9 \pm 0.7_{\mathrm{SD}}{ }^{\circ} \mathrm{C}$, W.1wr.v1: $10.3 \pm 0.5_{\mathrm{SD}}$ ${ }^{\circ} \mathrm{C}$, Welsh test: $\mathrm{t}_{\mathrm{w}}=2.14$, df $\left.=40, P=0.16\right)$. In the second vicennium (1994-2014), the increase of temperature turned faster in both invasion routes, especially in the lower sections (Fig. 4). During that time, the temperatures in lower sections were significantly higher compared to the upper sections within the corridors, the eastern (E.upr.v2: $8.8 \pm 0.7_{\mathrm{SD}}{ }^{\circ} \mathrm{C}$,
E.lwr.v2: $9.5 \pm 0.8_{\mathrm{SD}}{ }^{\circ} \mathrm{C}$, Welsh test: $\mathrm{t}_{\mathrm{W}}=2.89, \mathrm{df}=$ $36, P=0.04$ ) and the western (W.upr.v2: $10.7 \pm 0.8_{\mathrm{SD}}$ ${ }^{\circ} \mathrm{C}$, W.lwr.v2: $10.3 \pm 0.8_{\mathrm{SD}}{ }^{\circ} \mathrm{C}$, Welsh test: $\mathrm{t}_{\mathrm{w}}=3.30$, $\mathrm{df}=36, P=0.02$ ). They were also higher compared to the temperature conditions in the previous vicennium (Table 2). As a consequence of these distinct dynamics, temperature conditions in the upper sections became similar to those which had been reported from the lower sections in the first vicennium. Moreover, the mean temperatures in the upper sections during the second vicennium became higher than those recorded in the lower sections in the years 1973-1993. This phenomenon was observed in both, the eastern (E.upr.v2: $8.8 \pm 0.7_{\mathrm{SD}}{ }^{\circ} \mathrm{C}$, E.lwr.v1: $8.5 \pm$ $1.1_{\mathrm{SD}}{ }^{\circ} \mathrm{C}$, Welsh test: $\mathrm{t}_{\mathrm{W}}=-0.82$, df $=38, P=0.42$ ) and the western, corridors (W.upr.v2: $10.7 \pm 0.8_{\mathrm{SD}}{ }^{\circ} \mathrm{C}$, E.lwr.v1: $10.3 \pm 0.5_{\mathrm{SD}}{ }^{\circ} \mathrm{C}$, Welsh test: $\mathrm{t}_{\mathrm{W}}=-1.97$, df $=38, P=0.17$ ). 


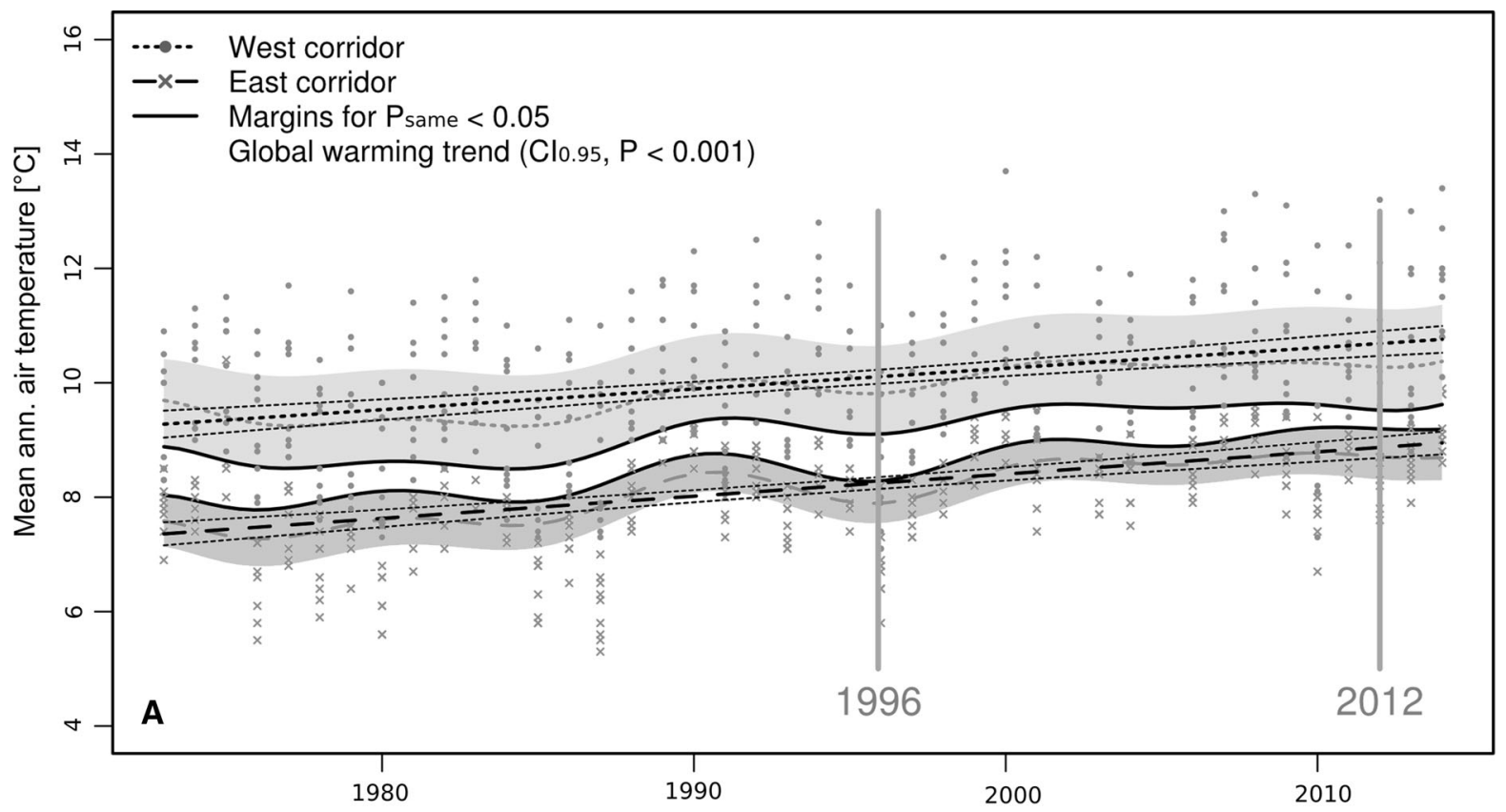

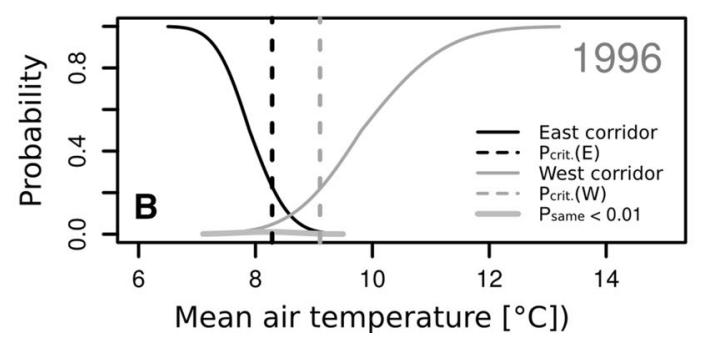

Fig. 3 Mean air temperatures of the eastern and the western invasion route over the last 40 years with probability margins $(P<0.05)$ for mean annual temperatures identical or overlapping (a). 1996 and 2012, years with greatest $(P<0.01)$

\section{Discussion}

Dikerogammarus villosus is one of the most expansive invasive freshwater species in Europe (Bij de Vaate et al. 2002; Grabowski et al. 2007a). It immigrated from the native Ponto-Caspian region to the other parts of Europe via two different routes. As a result, two separate populations differing with respect to their geographic origin and genetic structure (Grabowski et al. 2007a; Rewicz et al. 2015) may be found in Europe, namely in Poland. The killer shrimp, as majority of alien amphipods in Europe, occurs predominantly in large rivers, artificial canals and dam reservoirs. High tolerance of these species to wide range of temperature and salinity values facilitates their colonization of anthropogenic, highly polluted

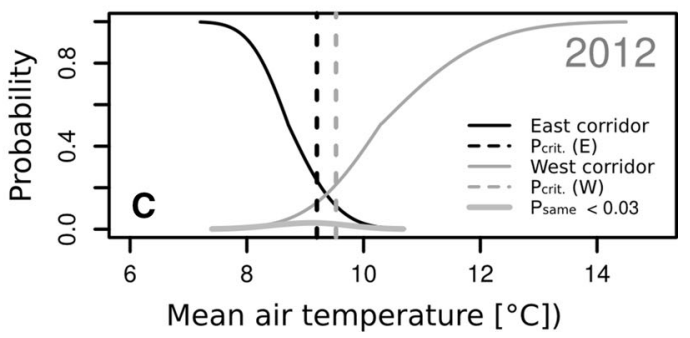

resp. smallest $(P<0.03)$ difference of temperature between the corridors. Probability distributions for 1996 (b) and 2012 (c). Detailed information is given in the text

water bodies (Grabowski et al. 2009). Our results revealed higher relative HSP70 expression in the eastern population of the killer shrimp than in the western one. Such higher level of HSP expression indicates higher sensitivity of the organisms to physiological stress (Morris et al. 2013). Recently, it was confirmed by Tomanek and Somero (2000), who compared heat-shock responses of two marine snails Tegula spp.. The authors observed that the species with higher level of HSP70 expression experienced stronger thermal stress and incurred greater thermal damage than the other one. Similar results were obtained during the recent experiments upon Gammarus pulex Linnaeus, 1758 which revealed that its northern populations with higher HSP70 expression were more sensitive to thermal stress than the southern 


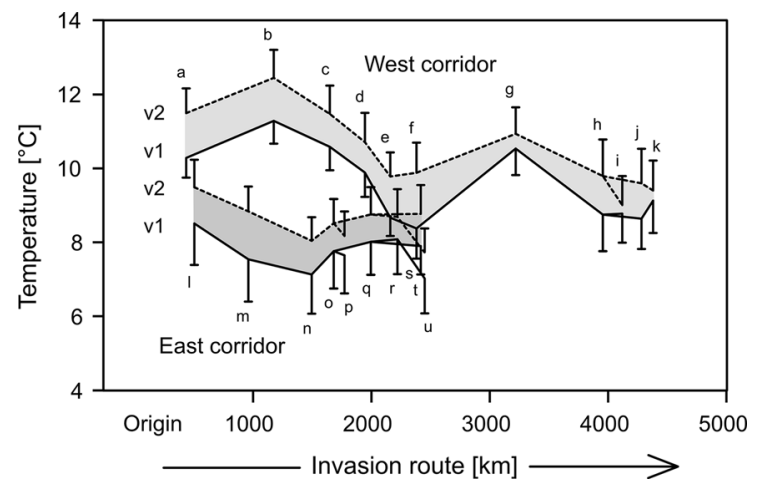

Fig. 4 Mean annual air temperatures along the eastern (dark grey) and the western (light grey) corridors of the invasion routes invasion of D. villosus toward central Europe. Shaded fields represent the mean increase of temperature between first (v1) and second (v2) vicennia. Means and standard deviations showing for measurement sites (a-k: Bucharest, Belgrade, Budapest, Vienna, Linz, Regensburg, Düsseldorf, Słubice, Szczecin, Wroclaw, Opole; 1-u: Dnipropetrovsk, Kiev, Pinsk, Brest, Włodawa, Warsaw, Torun, Cracow, Gdansk)

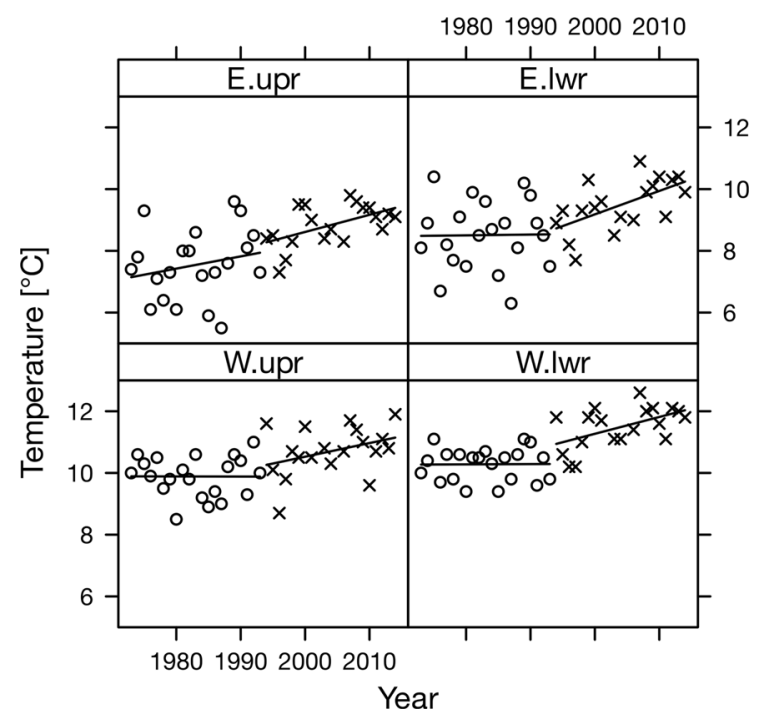

Fig. 5 Mean air temperatures and trends over time for both invasion corridors during the last 40 years, split into first (circle) and second (cross) vicennia (20-years intervals), eastern (E), western (W) invasion corridor, upper (upr), and lower (lwr) section. Test statistics for multiple spatiotemporal comparisons are given in Table 2

ones (Cottin et al. 2015). On the other side, it is already known that in reality the morphospecies G. pulex contains several local cryptic lineages different in molecular terms and with different evolutionary histories that may result in such physiological differences (Lagrue et al. 2014). Our results showed that populations of the killer shrimp having different genetic background and coming from two climaticgeographical regions differed in their reaction to thermal stress. Apparently, the individuals from the western invasion route are more tolerant to higher temperatures than those from the eastern population. It is not obvious whether such physiological differences are a by-product of different genetic composition of both populations or result directly from their adaptations to local climatic conditions.

However, it is known that the ability of organisms to tolerate temperature stress depends on the thermal history of their habitat (Feder and Hofmann 1999). In case of invasive species the thermal conditions in invasion routes may pose a strong impact on their dispersal success. For D. villosus the pathways led through the major European rivers like Danube and Dnieper, differing in thermal conditions. This may provide an explanation for an odd history of western invasion of $D$. villosus. For the first time it was reported in the middle Danube in 1926 and for over 70 years it has not dispersed any further (Rewicz et al. 2014). Then, from 1989 it suddenly started to spread all over the Western Europe. This coincides with the rise of the temperature in the upper Danube area. Thus, we may speculate that such rise could possibly be one of the triggers for the further spread of this amphipod. In contrary, invasion of $D$. villosus along the eastern route was much slower. Killer shrimp was among a few Ponto-Caspian species introduced in Soviet times to artificial reservoirs built all along the Dnieper to enhance food sources for commercially harvested fishes (Zuravel 1965; Ioffe and Maximova 1968). On the other hand, the temperature in Dnieper area was lower than in the Danube region, and it has not changed significantly over the years. Such climate stability may help to explain why the eastern population coped worse with the thermal stress. These finding is congruent with the results of thermotolerance studies on another amphipod, Gammarus pulex, distributed along the thermal gradient in the Rhône Valley, where Cottin et al. (2012) confirmed that populations inhabiting colder habitats coped worse with the thermal stress. Considering the thermal conditions in the Vistula River on the east and in the Oder River on the west, which are current distribution boundaries of the two D. villosus populations originating from different sources (Dnieper and Danube delta, respectively), there are noticeable differences in 
Table 2 Multiple comparison and tests for temperature differences and rates of temperature change between contrasted combinations: eastern (E) versus western (W) corridor, upper (upr) versus lower (lwr) section, first (v1) versus second vicennium (v2)

\begin{tabular}{|c|c|c|c|c|c|c|c|c|c|c|c|c|}
\hline \multicolumn{2}{|c|}{ Combination } & \multicolumn{6}{|c|}{ Temperature difference } & \multicolumn{5}{|c|}{ Temperature change } \\
\hline L1 & $\mathrm{L} 2$ & $\mathrm{~T}_{1}$ & $\mathrm{~T}_{2}$ & $\mathrm{SE}_{\Delta}$ & $\mathrm{T}_{\mathrm{W}}$ & Df & $P_{\text {adj }}$ & $\delta \mathrm{T}_{1}$ & $\delta \mathrm{T}_{2}$ & $\mathrm{SE}_{\delta}$ & $\mathrm{F}_{\mathrm{dev}}$ & $P_{\mathrm{dev}}$ \\
\hline E.upr.v1 & E.lwr.v1 & 8.0 & 8.5 & 0.31 & 1.58 & 40 & 0.24 & 31 & 2 & 52 & 2.43 & 0.58 \\
\hline W.upr.v1 & W.lwr.v1 & 9.9 & 10.3 & 0.19 & 2.14 & 40 & 0.16 & 0 & 1 & 31 & 4.34 & 0.97 \\
\hline E.upr.v2 & E.lwr.v2 & 8.8 & 9.5 & 0.26 & 2.89 & 36 & 0.04 & 50 & 76 & 35 & 11.00 & 0.46 \\
\hline W.upr.v2 & W.1wr.v2 & 10.7 & 11.5 & 0.24 & 3.30 & 36 & 0.02 & 44 & 55 & 35 & 12.80 & 0.77 \\
\hline E.upr.v1 & E.upr.v2 & 8.0 & 8.8 & 0.26 & 2.86 & 38 & 0.04 & 31 & 50 & 41 & 0.05 & 0.66 \\
\hline E.lwr.v1 & E.lwr.v2 & 8.5 & 9.5 & 0.32 & 3.16 & 38 & 0.02 & 2 & 76 & 48 & 10.40 & 0.14 \\
\hline W.upr.v1 & W.upr.v2 & 9.9 & 10.7 & 0.23 & 3.54 & 38 & 0.01 & 0 & 44 & 37 & 13.10 & 0.23 \\
\hline W.lwr.v1 & W.1wr.v2 & 10.3 & 11.5 & 0.19 & 6.29 & 38 & 0.001 & 1 & 55 & 29 & 45.90 & 0.07 \\
\hline E.upr.v2 & E.lwr.v1 & 8.8 & 8.5 & 0.30 & -0.82 & 38 & 0.42 & 2 & 50 & 50 & 0.26 & 0.34 \\
\hline W.upr.v2 & W.lwr.v1 & 10.7 & 10.3 & 0.22 & -1.97 & 38 & 0.01 & 1 & 44 & 34 & 4.19 & 0.20 \\
\hline
\end{tabular}

Temperature means $\left[\mathrm{T}_{1}, \mathrm{~T}_{2}\left({ }^{\circ} \mathrm{C}\right)\right]$ for combinations compared, standard error $\left[\mathrm{SE}_{\Delta}\left({ }^{\circ} \mathrm{C}\right)\right]$ of difference, Welch test statistic $\left(\mathrm{t}_{\mathrm{W}}\right)$, degrees of freedom (df), adjusted (Holm) significance level for multiple Welch tests $\left(\mathrm{P}_{\mathrm{adj}}\right)$. Temperature change [ $\delta \mathrm{T} 1, \delta \mathrm{T} 2$ $\left.\left({ }^{\circ} \mathrm{C} \times 1000^{-1} \times \mathrm{a}^{-1}\right)\right]$ for comparison levels, standard error $\left[\mathrm{SE}_{\Delta}\left({ }^{\circ} \mathrm{C} \times 1000^{-1}\right)\right]$ of interaction of changes, $\mathrm{F}$ deviance statistic of interaction $\left(\mathrm{F}_{\mathrm{dev}}\right)$, interaction significance $\left(\mathrm{P}_{\mathrm{dev}}\right)$

climate conditions as well. We may speculate that this is one of the reasons why the eastern population has not invaded the Oder River, and the western one did not manage to colonize the Vistula.

It is expected that organisms already living in conditions closer to their thermal limits, reflected among other factors by the level of HSP expression, will be affected more by the climate change (Tomanek 2010). We may conclude that due to ongoing warming of the environment, the eastern population of $D$. villosus seems to be more heavily affected on the physiological level by the increase of the mean temperature, leading to significant energetic costs known to accompany the synthesis and functioning of HSPs at the increased levels (Feder et al. 1992; Krebs and Loeschke 1994). However considering the predictions for further climate warming, one can expect a similar pattern also in the western population within a foreseeable timeframe. The outcome might be different though, as populations from warmer regions may be limited in their ability to acclimate to even higher temperatures, whereas the populations from colder areas, although more sensitive to heat stress, can acclimatize to warmer conditions (Tomanek 2008).

Considering the thermal tolerance of both populations and global trend of climate change, it is possible to make some predictions about further spread of $D$. villosus. In case of eastern population, it may eventually spread northward to the Neman River and southward to the upper reach of Vistula. In case of the western population, it will probably continue to spread all over the Western Europe and possibly also to southern Europe. It may be also assumed that during next 20 years, when temperature in Vistula will reach current average temperature of Oder, the western population will spread eastward through Bydgoski Canal, finally facing the eastern population. We may speculate what will be the results of such encounter. Most probably hybridisation will occur as the two populations are not either phylogenetically or ecologically divergent which implies the absence of reproduction barrier (Mallet 2005). Crossing of such genetically diversified populations may lead to development of a super-hybrid which, due to outbreeding overdominance, could possibly be even more invasive than any of the parental populations (Krehenwinkel and Tautz 2013). On the other side, there is a risk of reducing the fitness of a hybrid via outbreeding depression (Lynch 1991; Gharrett et al. 1999). Due to the relatively low genetic distance between the above mentioned populations, the first possibility is more plausible. This may result in emergence of a potential super-invader-an even more effective invasive species having even wider range of thermal 
tolerance. Such super-hybrids were already observed in other cases like in snail Melanoides tuberculata or wasp Psyttalia lounsburyi (i.e. Facon et al. 2005; Benvenuto et al. 2012).

In summary, considering the climatic conditions in which both populations occur in nature and the results of HSP70 expression, we can conclude that eastern population of $D$. villosus is more sensitive to thermal stress than the western population. Hence its invasion potential may be lower than that of the latter, particularly in the face of the commonly observed global temperature rise (IPCC 2001, 2007). However, this assumption cannot be generalized on the entire stress response of an organism, because it consists of several protein groups, which expression or its lack can be different in particular species or according to different stress factors (Mayer 2010; Morris et al. 2013).

Acknowledgements The study was supported by the Erasmus Mobility Program of the European Union. We would like to thank Deula Santhosh Kumar, Tomasz Mamos and Piotr Gadawski for help in fieldwork and Nicole Breul and Olessja Becker for assistance in laboratory analyses.

Open Access This article is distributed under the terms of the Creative Commons Attribution 4.0 International License (http:// creativecommons.org/licenses/by/4.0/), which permits unrestricted use, distribution, and reproduction in any medium, provided you give appropriate credit to the original author(s) and the source, provide a link to the Creative Commons license, and indicate if changes were made.

\section{References}

Ba J, Hou Z, Platvoet D, Zhu L, Li S (2010) Is Gammarus tigrinus (Crustacea, Amphipoda) becoming cosmopolitan through shipping? Predicting its potential invasive range using ecological niche modeling. Hydrobiologia 649(1):183-194

Bącela K, Grabowski M, Konopacka A (2008) Dikerogammarus villosus (Sowinsky, 1894) (Crustacea, Amphipoda) enters Vistula: the biggest river in the Baltic basin. Aquat Invasions 3:95-98

Bedulina DS, Zimmer M, Timofeyev MA (2010) Sub-littoral and supra-littoral amphipods respond differently to acute thermal stress. Comp Biochem Physiol B Biochem Mol Biol 155(4):413-418

Benvenuto C, Cheyppe-Buchmann S, Bermond G, Ris N, Fauvergue $X$ (2012) Intraspecific hybridization, life history strategies and potential invasion success in a parasitoid wasp. Evol Ecol 26(6):1311-1329

Bij de Vaate A, Jazdzewski K, Ketelaars HAM et al (2002) Geographical patterns in range extension of Ponto-Caspian macroinvertebrate species in Europe. Can J Fish Aquat Sci 59:1159-1174

Boets P, Lock K, Goethals PL (2012) Assessing the importance of alien macro-Crustacea (Malacostraca) within macroinvertebrate assemblages in Belgian coastal harbours. Helgol Mar Res 66(2):175-187

Bollache L, Devin S, Wattier R, Chovet M, Beisel JN, Moreteau JC, Rigaud T (2004) Rapid range extension of the PontoCaspian amphipod Dikerogammarus villosus in France: potential consequences. Archiv für Hydrobiologie 160(1):57-66

Both C, Bouwhuis S, Lessells CM, Visser ME (2006) Climate change and population declines in a long-distance migratory bird. Nature 441(7089):81-83

Bradford MM (1976) A rapid and sensitive method for the quantitation of microgram quantities of protein utilizing the principle of protein-dye binding. Anal Biochem 72(1):248-254

Chown SL, Hoffmann AA, Kristensen TN, Angilletta MJ Jr, Stenseth NC, Pertoldi C (2010) Adapting to climate change: a perspective from evolutionary physiology. Clim Res 43(1-2):3-15

Cottin D, Roussel D, Foucreau N, Hervant F, Piscart C (2012) Disentangling the effects of local and regional factors on the thermal tolerance of freshwater crustaceans. Naturwissenschaften 99(4):259-264

Cottin D, Foucreau N, Hervant F, Piscart C (2015) Differential regulation of hsp70 genes in the freshwater key species Gammarus pulex (Crustacea, Amphipoda) exposed to thermal stress: effects of latitude and ontogeny. J Comp Physiol B 185:1-11

DAISIE (2009) Handbook of alien species in Europe. Springer, Dordrecht

Dextrase AJ, Mandrak NE (2006) Impacts of alien invasive species on freshwater fauna at risk in Canada. Biol Invasions 8:13-24

Dick JTA, Platvoet D (2000) Invading predatory crustacean Dikerogammarus villosus eliminates both native and exotic species. Proc R Soc Lond Ser B Biol Sci 267:977-983

Facon B, Jarne P, Pointier JP, David P (2005) Hybridization and invasiveness in the freshwater snail Melanoides tuberculata: hybrid vigour is more important than increase in genetic variance. J Evol Biol 18(3):524-535

Feder ME, Hofmann GE (1999) Heat-shock proteins, molecular chaperones, and the stress response: evolutionary and ecological physiology. Ann Rev Phys 61:243-282

Feder JH, Rossi JM, Solomon J, Solomon N, Lindquist S (1992) The consequences of expressing hsp70 in Drosophila cells at normal temperatures. Genes Dev 6(8):1402-1413

Früh D, Stoll S, Haase P (2012) Physico-chemical variables determining the invasion risk of freshwater habitats by alien mollusks and crustaceans. Ecol Evol 2(11):2843-2853

Gallardo B, Errea MP, Aldridge DC (2012) Application of bioclimatic models coupled with network analysis for risk assessment of the killer shrimp, Dikerogammarus villosus, in Great Britain. Biol Invasions 14(6):1265-1278

Genner MJ, Sims DW, Wearmouth VJ, Southall EJ, Southward AJ, Henderson PA, Hawkins SJ (2004) Regional climatic warming drives long-term community changes of British 
marine fish. Proc $\mathrm{R}$ Soc Lond B Biol Sci 271(1539):655-661

Gharrett AJ, Smoker WW, Reisenbichler RR, Taylor SG (1999) Outbreeding depression in hybrids between odd-and evenbroodyear pink salmon. Aquaculture 173(1):117-129

Grabowski M, Jażdżewski K, Konopacka A (2007a) Alien Crustacea in Polish waters-Amphipoda. Aquat Invasions 2:25-38

Grabowski M, Bạcela K, Konopacka A (2007b) How to be an invasive gammarid (Amphipoda: Gammaroidea): comparison of life history traits. Hydrobiologia 590:75-84

Grabowski M, Bącela K, Konopacka A, Jażdżewski K (2009) Salinity-related distribution of alien amphipods in rivers provides refugia for native species. Biol Invasions 11:2107-2117

Havel JE, Lee CE, van der Zanden MJ (2005) Do reservoirs facilitate invasions into landscapes? Bioscience 55:518-525

Hellmann JJ, Byers JE, Bierwagen BG, Dukes JS (2008) Five potential consequences of climate change for invasive species. Conserv Biol 22(3):534-543

Henkel SK, Hofmann GE (2008) Differing patterns of hsp70 gene expression in invasive and native kelp species: evidence for acclimation-induced variation. J Appl Phycol 20(5):915-924

Hochachka PW, Somero GN (2002) Biochemical adaptation: mechanism and process in physiological evolution. Oxford University Press, Oxford

Holdich DM, Poeckl M (2007) Invasive crustaceans in European inland waters. In: Gherardi F (ed) Biological invaders in inland waters: profiles, distribution, and threats. Springer, Dordrecht, pp 29-76

Holm S (1979) A simple sequentially rejective multiple test procedure. Scand J Stat 6:65-70

Ioffe TI, Maximova LP (1968) Biology of some crustaceans, perspective for acclimatization in reservoirs. Proc GosNIORKH 67:87-104

IPCC (2001) Climate change 2001: the scientific basis-contribution of working group I to the third assessment report of the intergovernmental panel on climate change. Cambridge University Press, New York

IPCC (2007) Climate change 2007: the physical science basis. Cambridge University Press, New York

Jażdżewski K, Konopacka A (2000) Immigration history and present distribution of alien crustaceans in Polish waters. In: Von Vaupel Klein JC, Schram FR (eds) The biodiversity crisis and crustacea. 4th International Crustacean Congress, Amsterdam, July 1998, vol 2. A.A. Balkema Publisher, Rotterdam, pp 55-64

Jażdżewski K, Konopacka A, Grabowski M (2002) Four PontoCaspian and one American gammarid species (Crustacea, Amphipoda) recently invading Polish waters. Contrib Zool 71:115-122

Jażdżewski K, Konopacka A, Grabowski M (2004) Recent drastic changes in the gammarid fauna of the Vistula River deltaic system in Poland caused by alien invaders. Div Distrib 10:81-88

Jażdżewski K, Konopacka A, Grabowski M (2005) Native and alien malacostracan Crustacea along the Polish Baltic Sea coast in the twentieth century. Oceanol Hydrobiol Stud 24(Suppl 1/2005):195-208
Johnson PTJ, Olden JD, van der Zanden MJ (2008) Dam invaders: impoundments facilitate biological invasions into freshwaters. Front Ecol Environ 6:359-365

Konopacka A (2004) Inwazyjne skorupiaki obunogie (Crustacea, Amphipoda) w wodach Polski. Przegląd Zoologiczny 48:141-162

Krebs RA, Loeschcke V (1994) Costs and benefits of activation of the heat-shock response in Drosophila melanogaster. Functional Ecology 8:730-737

Krehenwinkel H, Tautz D (2013) Northern range expansion of European populations of the wasp spider Argiope bruennichi is associated with global warming-correlated genetic admixture and population-specific temperature adaptations. Mol Ecol 22(8):2232-2248

Kültz D (2003) Evolution of the cellular stress proteome: from monophyletic origin to ubiquitous function. J Exp Biol 206:3119-3124

Lagrue C, Wattier R, Galipaud M, Gauthey Z, Rullmann J-P, Dubreuil C, Rigaud T, Bollache L (2014) Confrontation of cryptic diversity and mate discrimination within Gammarus pulex and Gammarus fossarum species complexes. Freshw Biol 59:2555-2570

Lambertini M, Leape J, Marton-Lefevre J, Mittermeier RA, Rose M, Robinson JG, Stuart SN, Waldman B, Genovesi P (2011) Invasives: a major conservation threat. Science 333:404-405

le Roux PC, McGeoch MA (2008) Rapid range expansion and community reorganization in response to warming. Global Change Biol 14:2950-2962

Lee GJ, Vierling E (2000) A small heat shock protein cooperates with heat shock protein 70 systems to reactivate a heatdenatured protein. Plant Physiol 122:189-197

Lindquist S, Craig EA (1988) The heat-shock proteins. Annu Rev Genet 22:631-677

Lövei GL (1997) Biodiversity: global change through invasion. Nature 388:627-628

Lynch M (1991) The genetic interpretation of inbreeding depression and outbreeding depression. Evolution 45:622-629

Maazouzi C, Piscart C, Legier F, Hervant F (2011) Ecophysiological responses to temperature of the "killer shrimp" Dikerogammarus villosus: is the invader really stronger than the native Gammarus pulex? Comp Biochem Physiol A Mol Integr Physiol 159(3):268-274

MacNeil C, Dick JTA, Elwood RW (2000) Differential physicochemical tolerances of amphipod species revealed by field transplantations. Oecologia 124:1-7

Mallet J (2005) Hybridization as an invasion of the genome. Trends Ecol Evol 20(5):229-237

Mayer MP (2010) Gymnastics of molecular chaperones. Mol Cell 39(3):321-331

Møller AP, Rubolini D, Lehikoinen E (2008) Populations of migratory bird species that did not show a phenological response to climate change are declining. Proc Natl Acad Sci 105(42):16195-16200

Mordukhai-Boltovskoi FD (1969) Besonderheiten der kaspischen Fauna im Bassin der Donau. Limnologische Donauforschungen, Kiev, pp 98-105

Morris JP, Thatje S, Hauton C (2013) The use of stress-70 proteins in physiology: a re-appraisal. Mol Ecol 22(6):1494-1502 
Nesemann H, Pöckl M, Wittmann KJ (1995) Distribution of epigean Malacostraca in the middle and upper Danube (Hungary, Austria, Germany). Misc Zool Hung 10:49-68

Panov VE, Alexandrov B, Arbačiauskas K, Binimelis R, Copp GH, Grabowski M et al (2009) Assessing the risks of aquatic species invasions via European inland waterways: from concepts to environmental indicators. Integr Environ Assess Manag 5(1):110-126

Parmesan C (2006) Ecological and evolutionary responses to recent climate change. Annu Rev Ecol Evol Syst 37:637-669

Pörtner HO, Knust R (2007) Climate change affects marine fishes through the oxygen limitation of thermal tolerance. Science 315(5808):95-97

R Core Team (2015) R: A language and environment for statistical computing. R Foundation for Statistical Computing, Vienna, Austria. http://www.R-project.org/

Rahel FJ, Olden JD (2008) Assessing the effects of climate change on aquatic invasive species. Conserv Biol 22(3):521-533

Rewicz T, Grabowski M, MacNeil C, Bacela-Spychalska K (2014) The profile of a 'perfect'invader: the case of killer shrimp, Dikerogammarus villosus. Aquatic Invasions 9(3):267-288

Rewicz T, Wattier R, Grabowski M, Rigaud T, Bącela-Spychalska K (2015) Out of the Black Sea: Phylogeography of the Invasive Killer Shrimp Dikerogammarus villosus across Europe. PLoS ONE 10(2):e0118121

Sargent LW, Dolladay SW, Civich AP, Opsahl SP (2011) Physicochemical habitat association of a native and nonnative crayfish in the Lower Flint river, Georgia: implications for invasion success. Biol Invasions 13:499-511

Shatilina ZM, Riss WH, Protopopova MV, Trippe M, Meyer EI, Pavlichenko VV, Bedulina DS, Axenov-Gribanov DV, Timofeyev MA (2011) The role of the heat shock proteins (HSP70 and sHSP) in the thermotolerance of freshwater amphipods from contrasting habitats. J Thermal Biol 36:142

Šidagyte E, Solovjova S, Šniaukštaite V, Šiaulys A, Olenin S, Arbačiauskas K (2017) The killer shrimp Dikerogammarus villosus (Crustacea, Amphipoda) invades Lithuanian waters, South-Eastern Baltic Sea. Oceanologia 59(1):85-91

Somero GN (2010) The physiology of climate change: how potentials for acclimatization and genetic adaptation will determine 'winners' and 'losers'. J Exp Biol 213(6):912-920

Sorte CJB, Hofmann GE (2005) Thermotolerance and heatshock protein expression in Northeastern Pacific Nucella species with different biogeographical ranges. Mar Biol 146:985-993

Steltzer H, Post E (2009) Seasons and life cycles. Science 324(5929):886-887

Strayer DL (2010) Alien species in fresh waters: ecological effects, interactions with other stressors, and prospects for the future. Freshw Biol 55:152-174

Tockner K, Uehlinger U, Robinson CT (2009) Rivers of Europe. Academic Press, Cambridge

Tomanek L (2008) The importance of physiological limits in determining biogeographical range shifts due to global climate change: the heat-shock response. Physiol Biochem Zool 81(6):709-717

Tomanek L (2010) Variation in the heat shock response and its implication for predicting the effect of global climate change on species' biogeographical distribution ranges and metabolic costs. J Exp Biol 213(6):971-979

Tomanek L, Sanford E (2003) Heat-shock protein 70 (Hsp70) as a biochemical stress indicator: an experimental field test in two congeneric intertidal gastropods (Genus: Tegula). Biol Bull 205:276-284

Tomanek L, Somero GN (2000) Time course and magnitude of synthesis of heat-shock proteins in congeneric marine snails (genus Tegula) from different tidal heights. Physiol Biochem Zool 73(2):249-256

Tomanek L, Zuzow MJ (2010) The proteomic response of the mussel congeners Mytilus galloprovincialis and $M$. trossulus to acute heat stress: implications for thermal tolerance limits and metabolic costs of thermal stress. J Exp Biol 213:3559-3574

Towbin H, Staehelin T, Gordon J (1979) Electrophoretic transfer of proteins from polyacrylamide gels to nitrocellulose sheets: procedure and some applications. Proc Natl Acad Sci 76(9):4350-4354

Walther GR, Post E, Convey P, Menzel A, Parmesan C, Beebee TJ et al (2002) Ecological responses to recent climate change. Nature 416(6879):389-395

Weitere M, Vohmann A, Schulz N, Linn C, Dietrich D, Arndt H (2009) Linking environmental warming to the fitness of the invasive clam Corbicula fluminea. Glob Change Biol 15:2838-2851

Wijnhoven S, van Riel MC, van der Velde G (2003) Exotic and indigenous freshwater gammarid species: physiological tolerance to water temperature in relation to ionic content of the water. Aquat Ecol 37:151-158

Zuravel PA (1965) Ob akklimatizacii fauny limanno-kaspijskoj fauny v novych vodoemach S.S.S.R. Gidrobiologičeskij Žurnal 1:59-63 